\title{
Measurement of ethylene production during banana ripening
}

\author{
Marc ChILlet $^{1 *}$, Luc de LAPEYRe de Bellaire ${ }^{2}$, Olivier HuberT ${ }^{3}$, Didier MbéGuiÉ-A-MbéGuiÉ ${ }^{3}$ \\ ${ }^{1}$ CIRAD, Persyst, UMR \\ Qualisud, Fac. Farm. \\ Univ. Sao Paulo, \\ avenida Lineu Prestes, \\ 580 , Bloco 14, \\ 05508-900 Saõ Paulo, SP, \\ Brasil \\ marc.chillet@cirad.fr \\ 2 CIRAD, Persyst, UPR

\section{Measurement of ethylene production during banana ripening.} \\ Abstract - Introduction. This protocol aims at measuring fruit ethylene production during \\ ripening. It can be used to compare ethylene production between different banana varieties \\ or to compare ethylene production between fruit produced in different pedo-climatic condi- \\ tions. The principle, key advantages, starting plant material, time required and expected \\ results are presented. Materials and methods. This part describes the required laboratory \\ materials and the three steps necessary for calculating the amount of ethylene produced \\ during banana postharvest ripening. Possible troubleshooting is considered.
}

Systèmes bananes et ananas, CARBAP, BP 832, Douala, Cameroon

luc.de_lapeyre@cirad.fr

${ }^{3}$ CIRAD, Persyst, UMR Qualitrop, Station de Neufchâteau, Sainte-Marie, 97130 Capesterre-Belle-Eau, Guadeloupe

olivier.hubert@cirad.fr, didier.mbeguie-a-mbeguie @cirad.fr

\section{France / Musa sp. / methods / fruits / measurement / ripening / ethylene}

\section{Mesure de la production d'éthylène pendant la maturation de la banane.}

Résumé - Introduction. Le protocole vise à mesurer la production d'éthylène du fruit pendant la maturation. Il peut être utilisé pour comparer la production d'éthylène entre différentes variétés de bananes ou pour comparer la production d'éthylène entre fruits produits dans différentes conditions pédoclimatiques. Le principe, les principaux avantages, le matériel végétal requis, le temps nécessaire aux mesures et les résultats escomptés sont présentés. Matériel et méthodes. Cette partie décrit le matériel de laboratoire requis et les trois étapes nécessaires pour calculer la quantité d'éthylène produit pendant la maturation après récolte de la banane. De possibles anomalies sont évoquées.

France / Musa sp. / méthode / fruits / mesure / maturation / éthylène

\section{Introduction}

\section{Application}

${ }^{*}$ Correspondence and reprints

Fruits, 2008, vol. 63, p. 253-254 (C) 2008 Cirad/EDP Sciences All rights reserved DOI: $10.1051 /$ fruits:2008019 www.fruits-journal.org
This protocol aims at measuring fruit ethylene production during ripening. The ripening process involves the production of ethylene, which, in turn, controls several physiological events such as loss of firmness, peel discoloration, sugar biosynthesis, etc. This method can be used to compare ethylene production between different banana varieties or to compare ethylene production between fruit produced in different pedo-climatic conditions.

\section{Principle}

Bananas are climacteric. This method is designed to initiate fruit ripening with an ethylene-like gas such as acetylene or propylene and to measure fruit ethylene production by gas chromatography [1].

\section{Key advantages}

This protocol makes it possible to obtain an accurate measurement of the ethylene production potential of banana fruits.

\section{Starting material}

This protocol uses green bananas harvested 2-3 days prior to testing. 


\section{Time required}

Each measurement of ethylene production lasts $2 \mathrm{~min}$.

\section{Expected results}

Around $2-50 \mu \mathrm{L}$ ethylene $\cdot \mathrm{kg}^{-1}$ fresh material $\cdot h^{-1}$ should be released during the initial ripening phases and can be measured with the method proposed.

\section{Materials and methods}

\section{Laboratory materials}

The protocol requires a gas chromatograph (GC) with a flame ionisation detector (FID), a 2-3-L jar with a sampling septum, a climatic room at $(25 \pm 0.5)^{\circ} \mathrm{C}$, acetylene or propylene, a $250-\mu \mathrm{L}$ glass syringe, a $50-\mathrm{mL}$ plastic syringe and a test tube.

\section{Measurement of fruit ethylene production during ripening}

- Step 1. Choose and cut the fruit:

- choose a representative hand of the bunch for analysis (the middle hand is generally selected),

- cut off a banana from the hand,

- store the fruit for $2-3$ days at $20{ }^{\circ} \mathrm{C}$ to get rid of ripening inhibitors [2],

- weigh the banana and place it in the jar,

- measure air volume around the banana in the container (fill the jar with water and measure the water volume).

- Step 2. Acetylene (or propylene) treatment of bananas:

- to initiate ripening, inject approximately the equivalent of $10000 \mu \mathrm{L} \cdot \mathrm{L}^{-1}$ of acetylene or propylene with a $50-\mathrm{mL}$ plastic syringe through the septum. Note: lower concentrations of acetylene or propylene can also be used according to the fruit sensitivity threshold,

- store the jars with bananas at $25^{\circ} \mathrm{C}$ (optimal temperature for fruit ethylene synthesis).
- Step 3. Analysis of ethylene production:

- turn the jar over several times to homogenise the internal atmosphere,

- take $250 \mu \mathrm{L}$ from the head-space of jar air and inject it into the GC column,

- aerate the jars (leave them open for a few minutes),

- reseal the jars and store them again at $25^{\circ} \mathrm{C}$ for further measurement,

- after each measurement, calculate the amount of ethylene produced.

Note: the time between two measurements should be set prior the experiment. This time depends on the objective of the experimentation: if the objective is the analysis of ethylene production during the first stages of fruit ripening, a short interval between two measurements has to be selected (1$2 \mathrm{~h}$ ); if the objective is to measure total ethylene production during ripening, a long interval ( $24 \mathrm{~h}$ ) can be chosen.

Caution: if a 24-h interval is chosen, the jar must be large enough so that the $\mathrm{CO}_{2}$ released during fruit respiration does not affect ethylene synthesis $\left(2-3 \% \mathrm{CO}_{2}\right)$.

\section{Troubleshooting}

Two main problems can occur:

(a) No ethylene is detected: there is a leakage via the septum.

Solution: change the septum.

(b) The measurements indicate very low ethylene concentrations: there is too high a $\mathrm{CO}_{2}$ concentration. This can occur when the ratio [(total volume of the container)/ (volume of the fruit)] is too small.

Solution: choose a container better adapted to the volume of the fruit. As an example, for an 8-h interval between two measurements, a 3-L container is suitable for a 200$\mathrm{g}$ banana fruit.

\section{References}

[1] Thompson A.K., Seymour G.B., Comparative effect of acetylene and ethylene gas on initiation of banana ripening, Ann. Appl. Biol. 101 (1982) 407-410.

[2] Burg S.P., Burg E.A., Ethylene action and the ripening of fruits, Science 148 (1965) 11901196. 